\title{
超電導エネルギー貯蔵装置における 磁界シールドの一方式
}

\author{
正員 金 丸 保 典 (全沢工大) \\ 正員雨 宮好文 (千禁工大)
}

\section{1.まえがき}

電力需要が年々增加するにすかかわらず，電力供給 能力か順調に増加しない現在, 電力立定に礁保する ことは重要な問題である。発電量增やすにしてす， 建設用地の確保，環境的な諸問題など多くの矆点があ り、特に国土の狭い我加国では発電所建設が困難な㕸 況である。電力需要と供給能力についてみると, 最大 需要は夏期の冷房機器稼偟時であり，供給能力はこれ を賄うように設定されている。従って，他の季節では 㤨粭能力に余㭲が生じる。1日のうちで香最大需要時 間带故午後 1 〜 時に集中しており，その他の時間で 住供給能力に余裕加生じていることになる。夜間に余 剩電力を眝载し，尽間に放出すれば，新しい発電所の 建設定行わなくとす，現在の発電設備で十分な供給能 力を有するととになる。発電機も終日一定負荷運耺を

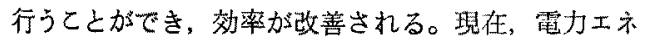
ルギー眝蔵装置として揚水発電所が䅝働しているが,

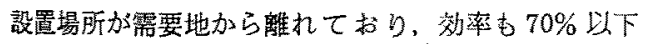
であるなど難点が多く，将来的に大摫模で效率の良い 詝蔵装䈯の実現が待たれる。

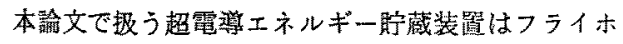
イール，蓞電池などの他の詝蔵装置に比孉して，非常 儿效率加良く，しか子大签量の装置が可能と考えられ ており，各抢面で研究が進められている(1)2)。近年の 超雪導材料の開発に6目覚しいものがあり，末すます 研究が進展して行くもの上思わ扎る。

一方，超電導コイルを用いるため，非常に强い磁兴 を発生し，電気機器類や生体采な亡゙，生活绶境に与え

\footnotetext{
A Method of Magnetic Shielding in Superconducting Magnetic Energy Storage. By Yasunori Kanamaru, Member (Kanazawn Institute of Technology) \& Yoshifumi Amemiya, Member (Chiba Institute of Technology).

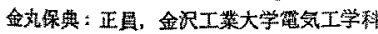

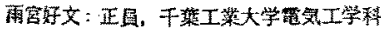

る强磁界の影響の問題，コイルに作用する電嵫力の間

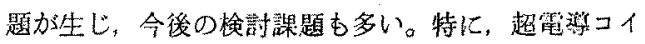
ルより漏れてくる磁界は地磁気の数干倍になるしとす 考元られ，磁気シールドの間題は重要なものになって くると腎われる。超䉓然コイルに対する磁気シールド

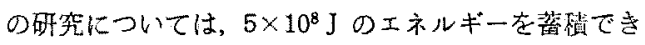

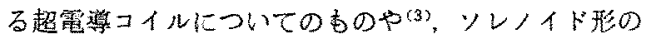
コイルを円筒形のシールド本で完全に覆ったときの磁 束分布空計算した例がある(4)。しがし，本諭文のよう に $1.8 \times 10^{13} \mathrm{~J}$ 程度のエネルギーが蓄積できる非常に 大形の超電導コイルを取报った例はなく，生活袈境で の磁界を考慮しての磁界解析は今後, 超電奨エネルギ 一詝蔵䒾置が累体的に設計されるうえで重要になって くるむの上思加れる。生活環境ての磁界をある一定 鹤凶下゙に抑えようとするための規準となる值について は，强磁界の生体などへの影響に関しては様なな研究

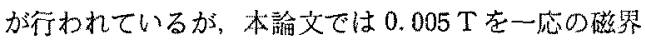
の安全基準亡教えている(5)(6)。

本馀文では，具体的に $5,000 \mathrm{MWh}$ 程度の電力管 蔵できる超電導エネルギ一沜藏装置について，その磁 界を数值解析し，䠉战コイルに対してシールドコイル をどのように設登したらよいか，更にシールド板をよ゙

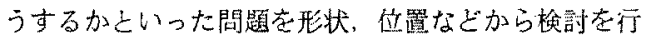

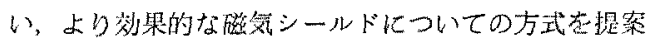
するものである。

以下にその結果比つて速へる。

\section{2. 超電導エネルギー貯藏装置の概要}

超筆導エネルギ一㭙藏装置については 1,000 10,000 MWh 程度の各種の娄の加提案さ机ている。 $1,000 \mathrm{MWh}$ は $3.6 \times 10^{12} \mathrm{~J}$ にもなり，その大ささが 想像される。形状は使用する超電然材料の問題，作用 する電磁応力の問題などの点を考虑しなりればなら

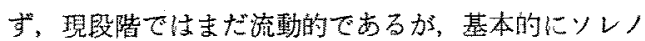

電学論 D, 108 巻 8 号, 昭 63 
表 1 超雷望エネルギー眝藏装置の例

Table 1. Examples of superconducting magnetic energy storage.

\begin{tabular}{|c|c|c|c|}
\hline & $\begin{array}{l}10,000 \mathrm{MWh} \\
\left(\begin{array}{l}\text { ウォスコン } \\
シ \text { 学 }\end{array}\right)\end{array}$ & 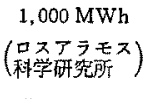 & 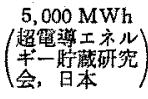 \\
\hline 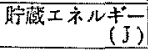 & $3.6 \times 10^{13}$ & $3.6 \times 10^{12}$ & $1.8 \times 10^{13}$ \\
\hline コイル半惩 $(\mathrm{m})$ & 103 & 66 & 200 \\
\hline コイル高さ (m) & 103 & 44 & 40 \\
\hline コイル形状 & ソレノイド形 & ソレノイト北 & ソレノイド玨 \\
\hline
\end{tabular}

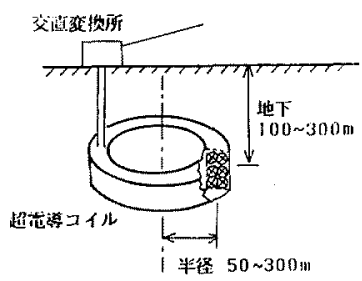

図 1 超電導エネルギー眝閔装蜸の概要

Fig. 1. Structure of superconducting magnetic energy storage.

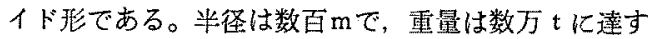
るため，地下 100 300 $\mathrm{m}$ に埋設し，コイルに作用す る電磁力を地下の岩整で支えようとするものである。 現在提案されているむのの具体例至 1 亿示す(1)。

本諭文では $5,000 \mathrm{MWh}$ 級の毛のを用いて具体的 な磁界解析を行う。图 1 にその概要を亦す。交直变换 所により交流 - 直流の変換を行い，超電導コイルに直 流を流し，電磁エネルギーとしてエネルギーの蓄積を 行い，放出のときは直流を交流に再变換して需要地に 送る。電流が流れている間は，抵抗が0であるため損 失はなく，極めて效率の良い工示ルギーの蓄積加可能 となり，更に葓本的には装犆自体には可趿部分がな く，静止機器さなるため效率は $90 \%$ 以上が望める(22。

\section{3. 磁界の近似解析}

超電導エネルギ一眝蔵に用いるコイルはソレノイド 形であるが、コイルの高さに対して半径が非常に大き

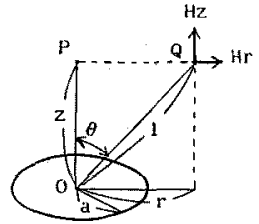

図 2 環状コイルによる磁界 $H, H_{2}$

Fig. 2. Magnetic field $H_{r}$ and $H_{z}$ generated by ring coil.
くなるので，近似的には図2のような環状のコイルと して考えることができる。従って，乙てでは初段階と して近似的な磁界の強さを求める。

コイルの中心 $O よ り ~ l(\mathrm{~m})$ 離れた任意の点 $Q$ にお ける磁界の強さは次式となる(7)。

$$
\begin{aligned}
H_{r}= & \frac{I}{2 \pi} \frac{1}{\sqrt{l^{2}+a^{2}+2 l a \sin \theta}} \frac{\cos \theta}{\sin \theta} \\
& \times\left(\frac{a^{2}+l^{2}}{l^{2}+a^{2}-2 l a \sin \theta} E(k)-K(k)\right)
\end{aligned}
$$

$$
\begin{aligned}
H_{z}= & \frac{I}{2 \pi} \frac{1}{V \frac{l^{2}+a^{2}+2 l a \sin \theta}{}} \\
& \times\left(\frac{a^{2}-l^{2}}{l^{2}+a^{2}-2 l a \sin \theta} E(k)+K(k)\right)
\end{aligned}
$$

$$
k=\sqrt{4 l a \sin \theta /\left(l^{2}+a^{2}+2 l a \sin \theta\right)}
$$

$K(k), E(k)$ は第 1 種，第 2 種の完全だ円積分である。 $K(k), E(k)$ は多項式で近以することかでき，lおよ び $\theta$ を与えることにより磁界の強さ $H_{r}, H_{x}$ 龙好 るこしができる。

図3において，P点は環状コイルの中心点 $O$ より $\Sigma(\mathrm{m})$ 離れて求り，P，Q点を地表面上の点とすれば， $z$ は地中への埋設の深さと考えればよく， $P$ 点より $Q$ 点に至る各部分での $B_{r}, B_{z}, B$ は地表面での磁束蜜度 ということになる。ここで， $B_{r} ， B_{z}$ は磁束密度の $r$ 方向， $z$ 方向成分定示す。

$$
\begin{aligned}
& B_{r}=\mu_{0} H_{r}, \quad B_{z}=\mu_{0} H_{z} \\
& B=\sqrt{B_{r}{ }^{2}+B_{z}{ }^{2}} \ldots \ldots \ldots . .
\end{aligned}
$$

ここで， $\mu_{0}$ : 空気中および地中の透磁率

半径 $a=200 \mathrm{~m}$ の超電導コイルが地下 $150 \mathrm{~m}$ に埋 設されている場合を考え，地表部分での磁束密度 $B_{r}$, $B=, B$ 求图 4 亿示す。との上き,コイルのインダ クタンスは $126.2 \mathrm{H}$ ，電流は $534.1 \mathrm{kA}$ 流すすのと考 え，蓄積エネルギー $W$ は

$$
W=\frac{1}{2} L I^{2}=1.8 \times 10^{13} \mathrm{~J}=5,000 \mathrm{MWh}
$$

と考えて計算を行っている。

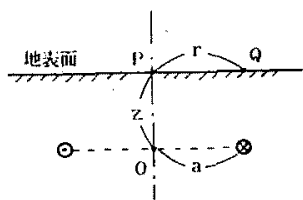

図 3 地中に埋設された環状コイル

Fig. 3. Ring coil in the earth. 


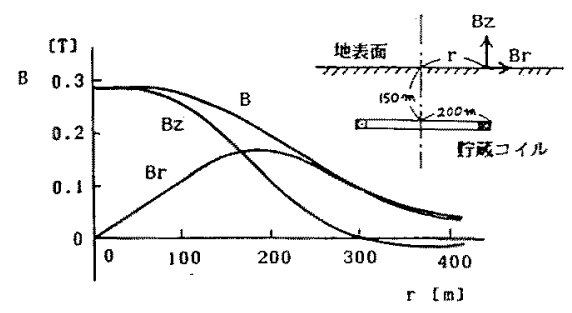

园 4 地表面における磁束密度分布

Fig. 4. Distribution of flux density on the surface of the earth.

図4加らかかるように、コイッの中心軸上にある点 Pに括いては $r$ 方向の磁束密度は0であり， $z$ 方向の 磁束密度のみ更存する。その值は $0.282 \mathrm{~T}$ と大きい 60になる。また，地表面上で磁束密度 $B$ が 0.005 工 以下となる所は中心軸よりか坆離れた所になる。 $0.005 \mathrm{~T}$ 以上の領域を例えば立入禁止の領域とすれ ば、この部分は半径 $780 \mathrm{~m}$ の領域となり，貯蔵コイ ルの平经 $200 \mathrm{~m}$ の約 4 倍にもなり，加りの広さ之 なり, 設置面䖽の点加らも超笔導エネルギ一淁置の難 点となる。

そこで，地上部分での碰界を小さくし，0.005 T 以 上の鋇牫の佳を小さくするためには超電導コイルを地 中梁く設置する加，シールドを行う方法がとるれなり ればならないしかし，前者は技術的に困難さが増す と共化建設貲屯增加すること加考えられるため，本論 文では後者についての検討を行った。

\section{4. シールドコイルを設置したときの磁界}

\section{解析}

图50ように，超電筫コイルの上部にシールド用超 電導コイルを喤置した場合について达へる。

シールドコイルを超簐酕状態にしておむ, 眝蔵コイ ルに電流を流すとシールドコイルに落滰起電力が生 し、シールドコイル内を通る総磁束 $\Phi$ 、は

$\Phi_{s}=0$

という条件を满足する。上方向の磁束と下方向の磁束 がキャンセルし，見け上 $\Phi_{s}=0$ となるわけである が, $\Phi_{s}=0$ でっっでシールドコイル内のすべての領

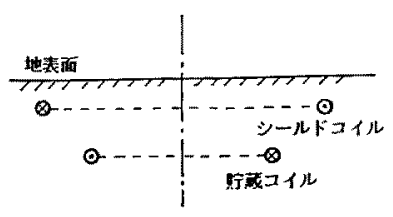

困 5 貯蔵コイルとシールドコイル

Fig. 5. Storaging coil and shielding coil.

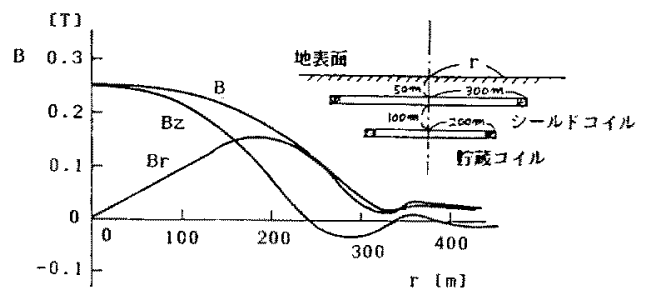

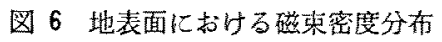
(シールドコイルがる場合)

Fig. 6. Distribution of flux density on the surface of the earth (with shielding coil).

域で磁束密度 $B_{s}$ 加0ということではない。

本論女では，シールドコイルを畹蔵コイルの上部 $100 \mathrm{~m}$ に設置し, その半径を $0 \sim 1,000 \mathrm{~m}$ の簕围で变 化さ甘た結果について検討を行った。その結果，シー ルドコイルの半经が $300 \mathrm{~m}$ のときに，地表面におけ 万磁界が $0.005 \mathrm{~T}$ 以下となる領域の半径は $710 \mathrm{~m}$ 上

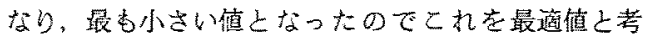
え, シールドコイルの半经は $300 \mathrm{~m}$ とした。とのと きシールドコイルには眝蔵コイルの約 $10 \%$ の電流が 誘起されたが，この電流值の決定にはシールドコイル 内の水平断面を通過する垂直方向の磁束について，水

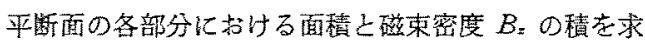
め，を机らをすべて加合せた古のが上下方向で打消 しあって0となる上うに，繰返し諳算して求めるとい う力法をとっだ。水平方向の磁柬については，軸対称 であるため左右で打消しあって0となるため考盧する 必要はない。このときの地表面での磁束密度の尔布を 图6に示要。

B:についてみる亡，0.005Tを超える領城は図 4 のときに比较して半径て $1 / 2$, 面積で $1 / 4$ 程度に綰小 されるという結果が得られた。 $B_{r}$ に閶しては $B$ : は どシールドの㩆著な效果吕出ていないように思われる がしかしシールドコイルを設置することは地表面で の磁界を小さするうえで有效なす抾であると結諭つ けられる。

5. シールドコイルとシールド板を設置した ときの磁界解析

前章ではシールドコイルを設置した場合の教果につ いて述へたが，更に地表面での㖙界在小さくするた め、シールド板を設䇺したときの紹果についてホす。 シールド板を考えるときは，計算族域中に 10 (空気 中およ己゙地中の透磁染) と $\mu_{i}$ (シールド板の透磁率)

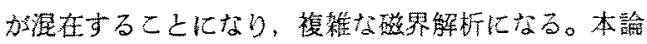
文においては，シールド板を設置したときの磁界解祈 


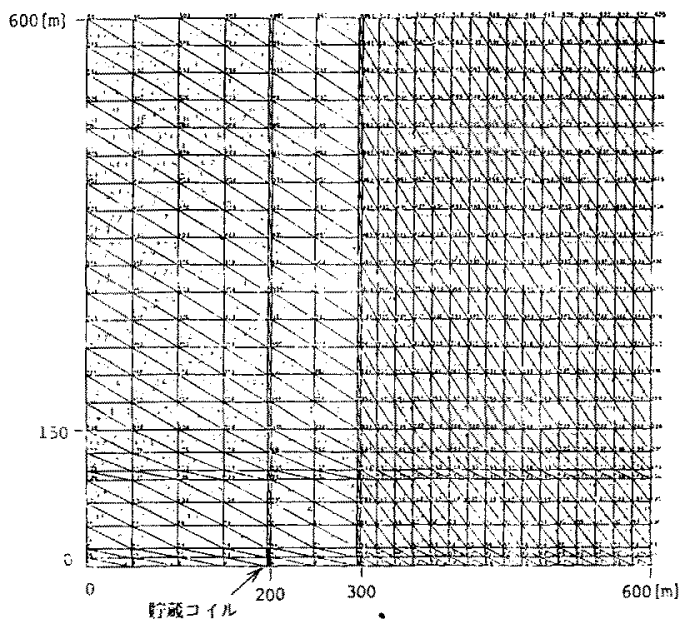

図 7 計算領域の三角形分割例

Fig. 7. Example of element subdivision of calculated area.

亿有限要素法を用いた ${ }^{(8) \sim(10)}$ 。

有限要素法の基本式については付録に示した。計算 を行う際は，計算領域を要素と呼ばれる小さな三角形 に分割して，各三角形の頂点(以下，節点と呼ふ）での ベクトルポテンシャルの值を得る。本諭文では, 節点 数 625 , 三角要素数 1,152 の計算領城についての結果 を得た。計算領域の分割図を四 7 亿示主。有限要素法 ではベクトルポテンシャル $\boldsymbol{A}$ の値が得られるため, $\boldsymbol{B}=\operatorname{rot} \boldsymbol{A}$ として $B_{r}, B_{k}$ 杉上び $B$ を求めて前章の 結果などとも比較検討した。

まず初炕，一番簡略な方法として円形のシール ド板を設置した場合について检討してみる。半径 $200 \mathrm{~m}$ の貯蔵コイルを地下 $150 \mathrm{~m}$ に埋設し, その上部 $100 \mathrm{~m}$ に半径 $300 \mathrm{~m}$ のシールドコイルを設置し, 更に 地表面比厚さ $25 \mathrm{~cm}$, 半䅅 $300 \mathrm{~m}, \mu=500 \mu 0$ である シールド板を設筐する。この方法は，超電導コイルの 上部一面比大きなシールド板を設䈯して地表面への瘺 れ磁界を小さくしょうとするものである。

そのときの地表面での磁束密度の分布を图8 亿示 す。な批較のために，图中にはシールドがない場合 とシールドコイルのみがある場合の磁束密度 $B$ 皏 女て示した。同図より，シールド板を設虽するととに より,シールドコイルのみの場合に比較して中心軸上 での磁界は約 $1 / 4$ 程度になるととがわかるまた， B. についての軽減效果禾シールド板がない場合に比 較して大きく, $B_{r}, B_{z}$ とも小さくなり。シールドは上 り効果的なものになる。しかし，ての場合は超笔導口 イルに大きなふなをするような形となり, シールド板

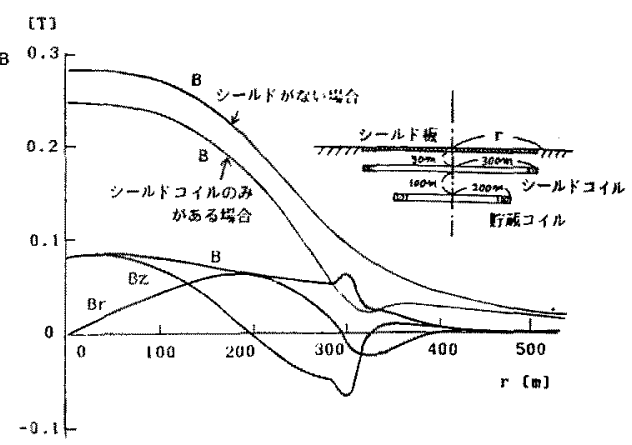

図 8 地表面比ける磁束密度分布(シールド コイルと円形シールド板がある場合）

Fig. 8. Distribution of flux density on the surface of the earth (with shielding coil and circular shielding plate).

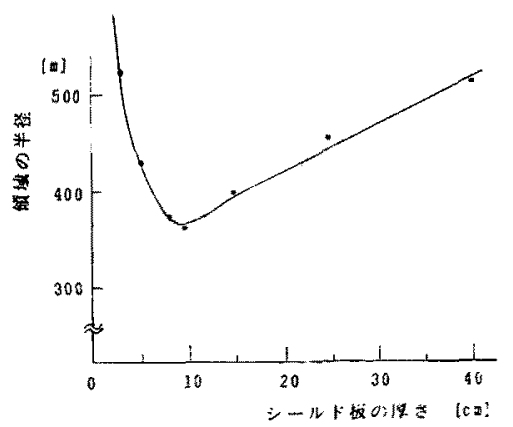

図 9 シールド板の厚さに対する領域の半径

Fig. 9. Radius of area vs. thickness of shield. ing plate.

がかなり大規模になり，材料の量的な問題，建設コス トの面からを最適設計とは言い難く，現実的ではない。 そこで円形のシールド板で虸な、シールド板の极 料を少なくし，加效果的にシールドを行う一つの方 法として、リング状のシールド板を設置した場合につ いて考える。リング状シールド板については，内半 径, 外半径, 厚さ，透酳率など様々な場合が洘えられ る。内半售に関しては，200 $500 \mathrm{~m}$ の範围で $50 \mathrm{~m}$ ごとに変化させ，そ机応して外半径す各種変化させ て, 最むシールドの勃果があるあのを導き出した。厚 さについても $1,3,5,8,10,25,40 \mathrm{~cm}$ の各㮔を 部算し、シールドの効果が大きい值として $10 \mathrm{~cm}$ を 得的。図9 k内半经 $300 \mathrm{~m}$, 外半径 $376 \mathrm{~m}$ 一定の上 きのシールド板の厚さに対する地表面での磁界か， $0.005 \mathrm{~T}$ 亡なる領域の半径の变化を示す。比透磁率は $50,100,250,500,1,000,2,000$ の各場合について の結果を得たが，比透磁率に対する磁界分布に大きな 


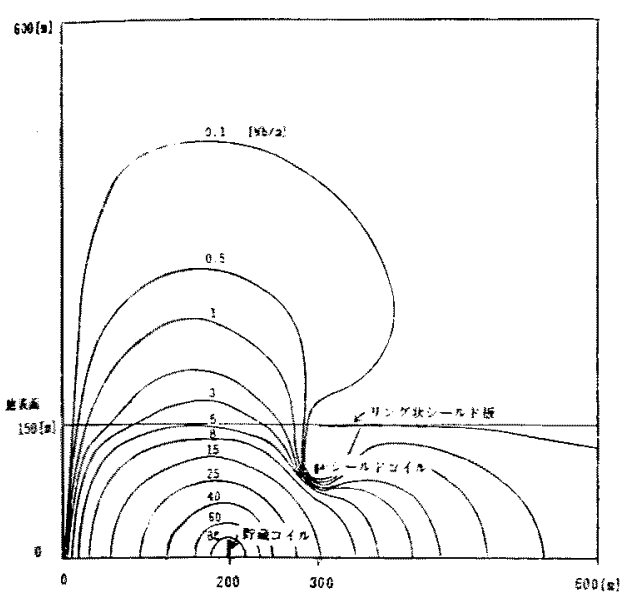

图 10 等ベクトルポテンシャル線の予直

Fig. 10. Distribution of equal vector potential lines.

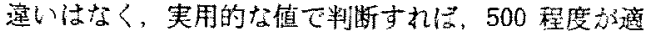

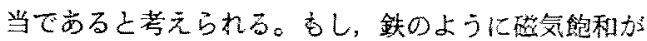
起こる材料では，磁㽞の堌加と其に比透磁率の変化秀

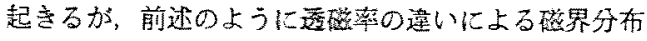

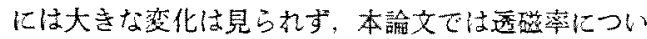
ては一定偭を用いた。

以上の各種の检詥より，ここでは比教的良い結果力 得られた場合について示方がその上きのリング状シ 一ルド板は内半径流 $300 \mathrm{~m}$ ，外半径は $376 \mathrm{~m}$ で 门，厚吉は $10 \mathrm{~cm}$, 比透磁率は 500 である。

图 10 は新算に上り得引れた等べトルホテンシャ ル綄を示す。シールドコイルむよびリング状シールド

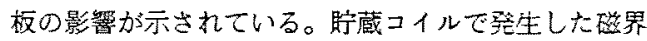
は，その上部にあるシールドコイルにより找中人戻

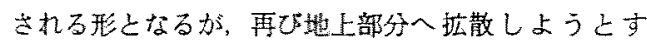

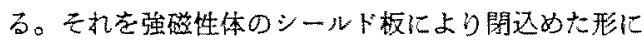
するのであるが，図 10 はよくその様子が示されてい

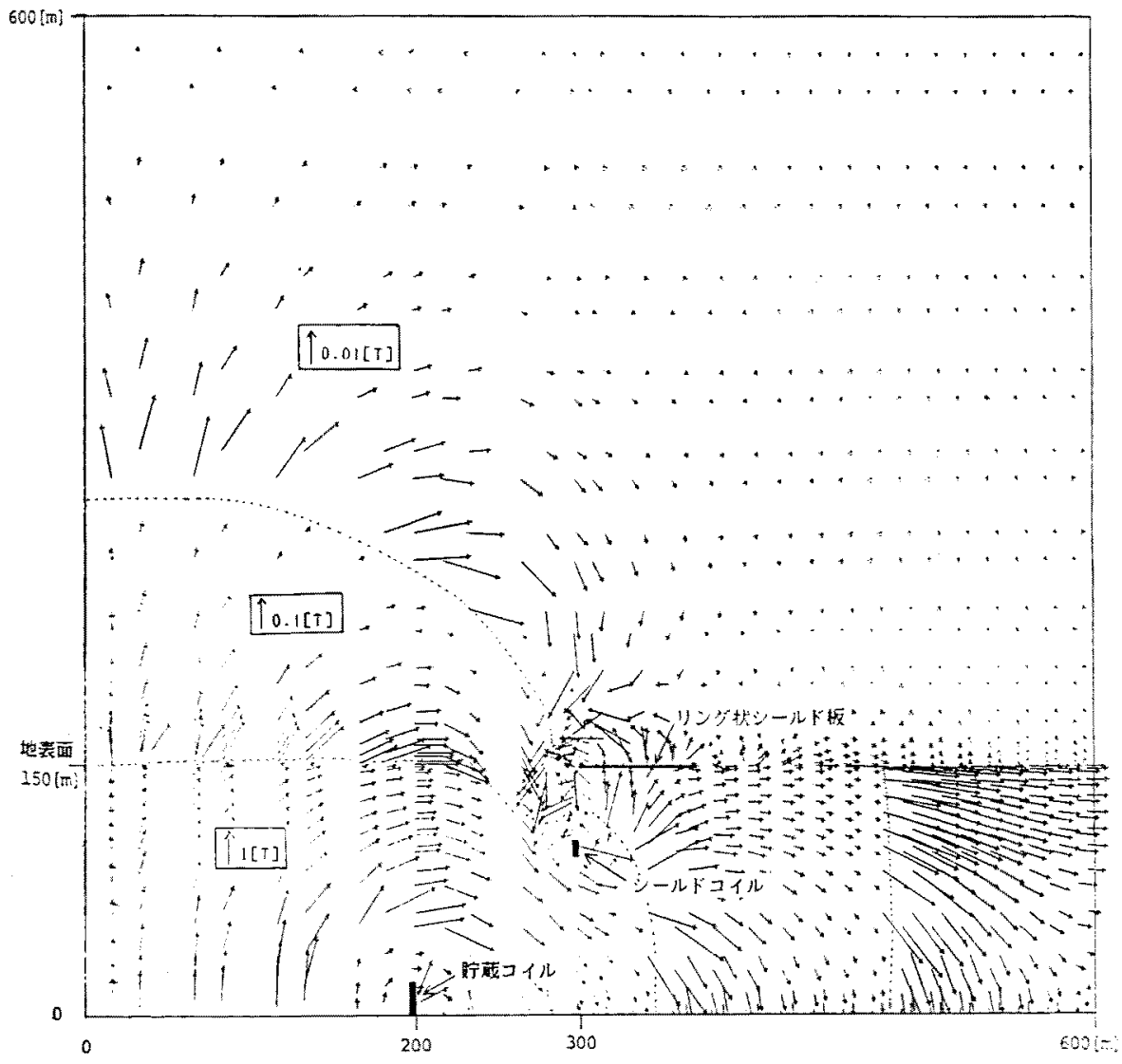

图 11 磁束密圈ベクトルの分布

Fig. 11. Distribution of flux density vectors. 


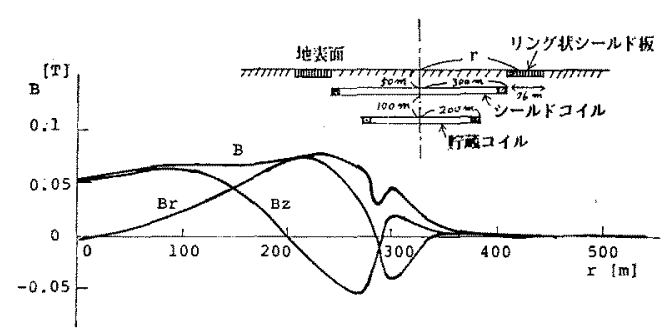

图 12 地表面における磁束密度分布(シールド コイルとリング状シールド板がある場合)

Fig. 12. Distribution of flux density on the surface of the earth (with shielding coil and ring shielding plate).

る。シールド板の位置と大きさを自由に変化させると とは計算上可能であるが, 内側, 外側どちらに移動さ せてむ图 10 ほどの良い結果は得られず, 同図に示す あのはかなり適切な位置の值を示しているすのと思わ れる。

図 11 は磁束密度 $B$ を計算領域の各部においてベク トル表示したあのである。複䧱な分布の様子がよく現 れてまり，特にシールド板近傍の分布は與味澡い。地 表面での磁束密度はシールド板の外側付近からは非常 に小さくなっていることがわかる。図 12 は地表部分 での磁束密度を示す。円形シールド板の場合と比較す ると磁束密度は非常に小さくなっており，磁束密度が $0.005 \mathrm{~T}$ 以下になる領域の半㙫は, 円班シールド板の ときは $410 \mathrm{~m}$, リング状シールド板のときは $362 \mathrm{~m}$ と なっている。これらの値は，シールドを行わない場合 の半堡 $780 \mathrm{~m}$ に比べて約半分になっている。

円形シールド板より、リング状シールドのほうが良 いという結果を得たが，その理由としては形状が大き く比透磁率む大きいシールド板を設置すると，その部 分に磁束が集中してくることになり，シールド板近傍 の磁界が強くなり過ぎて，逆効果になるためと考える れる。徒って, 本諭文のように磁界の上限值を超える 領域を小さくしようといった場合には，シールド板の 形状はリング状で十分であり，比透磁率も大きくなく てよいと思われる。また、シールド板を通る磁束は中 心より外側晌かう方向になるので, 必ずしす円周方 问に連䅴である必要はなく，断続的に直径方向に切断 して，何本かのスリットを設けてあよいてとになり， シールド效果を下げることなく, シールド板の面積を 小さくすることす可能であると思われる。

\section{6.むすび}

超大形の超電導コイルを用いる超電導エネルギー眝
蔵装置は，啰来的な電力エネルギー眝蔵装置の有望な あのの一つ上思われるが強磁界を発生し, 生体系や電 気機器系に与える影響は大きいと考えられる。本論文 は，超電導コイルの発生する強磁界をシールドするこ とにより, 極力, 生活環境部分での強磁界の影幚を防 ごうとするおのである。シールドがない場合とシール ドがある場合についての磁界の数值解析を行い，磁束 密度の分布を検討した。シールドについては，シール ドコイルと強磁性体のシールド板を置くことにより, 生活環境での磁束密度を $0.005 \mathrm{~T}$ 以下に抑え，加 $0.005 \mathrm{~T}$ を超える領域を極力小さくでることがわか った。

本研究で扱ったモデルは $5,000 \mathrm{MWh}$ の超笔導工 ネルギー盯葴装置で半径 $200 \mathrm{~m}$ に達する。研究の結 諭を以下に記す。

（1）超電導コイルを继下 150 200 $\mathrm{m}$ 程度に埋設 した亡きは地表面に0.2 0.3T の強磁界が生じ, $0.005 \mathrm{~T}$ を超える䕘域古広い。

(2) 地下数 $\mathrm{km}$ にまで理設深さを下げればよい 於，技術的な面，建設コストの面で不可能と思われ， 何らかのシールドが必要である。

(3) 地下 $150 \mathrm{~m}$ に眝蔵コイルを埋設し，地下 50 $\mathrm{m}$ Kシールドコイルを設置したとき，垂直方向の磁束 密度 $B_{z}$ については，そのシールド勃果は大きいが水

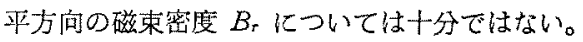

（4）更に，地表面に強磁性体のシールド板を設置 すれば生活環境での磁界を小さくでき，强磁界の存在 する領域を縮小できる。しかし，磁束を必要以上にシ ールド板近傍に集中させないためにも，その形状は適 切な半径，福をあったリング状のシールド板が良いと 思われ，最適に近いものを選べば，シールドの效果を 十分上げることができる。

(5) シールドコイルとシールド板の効果を示すた め, 磁束密度 $B$ が 0.005 以 以下になる領域の半径 $r$ を次に示す。

$$
\begin{aligned}
& \text { シールドがない場合 : } r=780 \mathrm{~m} \\
& \text { シールドコイルのみがある場合 }: r=710 \mathrm{~m} \\
& \text { シールドコイルと円形シールド板がある場合: }
\end{aligned}
$$

$$
r=410 \mathrm{~m}
$$

シールドコイルとリング状シールド板がある場合： $r=362 \mathrm{~m}$

本諭文での数值解析では，超電導コイルの形状，シ ールドコイルの北状，シールド板の形状と透磁率など について，様々な場合の磁界解新が容易に行うことが できる。今後は更に詳紐にシールドコイルの位㽞と大 きさ，シールド板の位置と大きさ，電磁応力について 
俆尌を行い，最適設計の指標ししたい。

(昭和 62 年 6 月 10 日受付, 同 62 年 11 月 20 日再受付)

\section{文献}

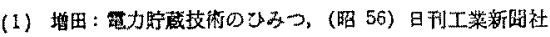

(2) A.W.B. Taylor (田中政) : 超伝導，(昭 49) 共立出版

(3) I. Ezaki \& F. Irie: "Solenoid-Type Shield Coil for Superconducting Magnetic Energy Storage", Proc. International Cryogenic Eng. Conf., 11, 479 (1986)

(4) T.J. Summer: "A calculation of the effect of a coaxial superconducting shild on the magnetic field distribution of an enclosed coaxial solenoid", J. Phys. D: Appl. Phys., 20, 692 (1957)

(5) Henry Aceto. Jr, et al. "Some Studies on the Biological Effects of Magnetic Fields", IEEE Trans, Magnetics, MAG-6, 368 (1970)

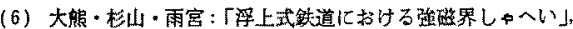
筆学食 B , 100,715 (嚾 55-12)

(7) Van Bladel: Electromagnetic Fields, (1964) McGraw-Hill

(8) S. Yamada, Y. Kanamaru \& K. Bessho: "The Transient Megnetization Frocess and Operation in the Plunger Tspe Electromagnet", IEEE Trans. Magnetics, MAG12. $1056(1976)$

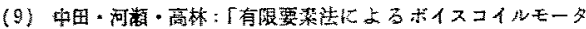

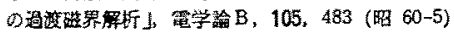

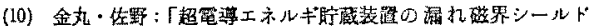

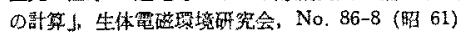

\section{付 録}

計算の対象上なる系は輁刘称をなしており，月柱坐 標系で取投うと好都合である。

Maxwell の方程式上り次式加成り立つ。

$$
\begin{aligned}
& \operatorname{rot} \boldsymbol{E}=-\frac{\partial \boldsymbol{B}}{\partial t} \ldots \\
& \operatorname{rot} \boldsymbol{H}=\boldsymbol{J}+\varepsilon \frac{\partial \boldsymbol{H}}{\partial t}
\end{aligned}
$$

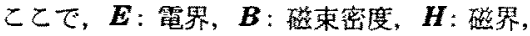

$\boldsymbol{J}:$ 電流密度, $\varepsilon$ : 誘電率

本諭文のような直流による磁界を求める場合を考至 ると，时間項を含む $-\partial \boldsymbol{B} / \partial t, \varepsilon(\partial \boldsymbol{E} / \partial t)$ は無視してよ い。また，磁束密度とベクトルポテンシャル $\boldsymbol{A}$ との 関係定 $\boldsymbol{B}=\operatorname{rot} \boldsymbol{A}$ として（付1)，(付 2 )式を変形する と次式が得られる。

$$
\operatorname{rot} \frac{1}{\mu} \operatorname{rot} A=\boldsymbol{J}
$$

円柱座標系において，ベクトルポテンジルAは $\theta$ 方向の代值をすつ6のとすれば $\boldsymbol{A}=\left(0, A_{*}, 0\right)$ と なり，(付 3 )式は次式之なる。

$$
\frac{\partial}{\partial r}\left\{\frac{1}{\mu r} \frac{\partial}{\partial r}\left(r A_{\theta}\right)\right\}+\frac{\partial}{\partial z}\left\{\frac{1}{\mu r} \frac{\partial}{\partial z}\left(r A_{\theta}\right)\right\}=-J
$$

风上のように，基本よなる德分方程式が得られたわ けであるか，との微分方程式はオイラーの微分方程式 の形に一致し，その解は $A_{0}$ に関する㲸関数に，エ ネルギー最小化の原理を適用して求妨たこきの值と等 洒である。沉関数を次に示す。

$$
\begin{aligned}
\mathscr{F} & =\iint_{R}\left(\int_{0}^{B} \frac{1}{\mu} b d b\right) r d r d z \\
& =-\iint_{R} J A_{\theta} r d r d z \quad \ldots .
\end{aligned}
$$

ことで，R:皘分鎮域

エネルギー最小化の原理を満足するには，次式を满 足する極值をとる $A_{\theta}$ を求めれ代よい。

$$
\frac{\partial \mathscr{F}}{\partial A_{\theta}}=0
$$

